\title{
PERSEPSI PERAWAT TENTANG KEBUTUHAN KEBUTUHAN SPIRITUAL DI RUANG ICU RSUD DR. TJITROWARDOJO PURWOREJO
}

\author{
Mugihartadi $^{1}$ \\ ${ }^{1}$ Program Studi DIII Keperawatan Akademi Keperawatan Pemkab Purworejo \\ Email: gik_kippi@yahoo.com
}

\begin{abstract}
ABSTRAK
Latar belakang: Kebutuhan dasar pasien meliputi kebutuhan fisik, psikologis, sosial dan spiritual. Kebutuhan spiritual diberikan kepada pasien di ruang ICU melalui layanan perawatan spiritual. Perawatan spiritual merupakan suatu praktik dan prosedur yang dilakukan oleh perawat pada pasien untuk memenuhi kebutuhan spiritual pasien melalui doa, shalat, dzikir etc. Tujuan: Penelitian ini bertujuan untuk menggali persepsi perawat tentang kebutuhan spiritual pasien. Metode: Metode yang digunakan dalam penelitian ini adalah dengan menggunakan eksplorasi deskriptif kualitatif. Hasil: Analisa data kualitatif menggunakan NVivo Plus Dua Belas menghasilkan tema kebutuhan spiritual pasien yang terdiri dari dua kategori yaitu pemberian dan pemenuhan. Kesimpulan: Kebutuhan spiritual merupakan kebutuhan dasar yang dibutuhkan oleh pasien di ruang ICU.
\end{abstract}

Kata kunci: kebutuhan dasar, kebutuhan spiritual, ICU

\begin{abstract}
Background: The basic needs of patients include physical, psychological, social and spiritual needs. Spiritual needs are provided to patients in the ICU through spiritual care services. Spiritual care is a practice and procedure performed by nurses on patients to meet the spiritual needs of patients through prayer, prayer, dhikr etc. Objective: This study aims to explore the nurse's perception of the patient's spiritual needs. Methods: The method used in this research is descriptive qualitative exploration. Results: Qualitative data analysis using NVivo Plus Dua Belas resulted in the theme of the patient's spiritual needs consisting of two categories, namely giving and fulfillment. Conclusion: Spiritual needs are basic needs needed by patients in the ICU.
\end{abstract}

Keywords: basic needs, spiritual needs, ICU

\section{Latar Belakang}

Kebutuhan dasar pasien meliputi kebutuhan fisik, psikologis, sosial dan spiritual (Hawari, 2012). Menurut Hamid (2010) keperawatan yang diberikan perawat tidak terlepas dari aspek spiritual, dan aspek spiritual merupakan bagian integral dari interaksi antara perawat dan klien. Perawat berusaha membantu memuaskan kebutuhan spiritual pasien dengan memenuhi kebutuhan spiritual pasien sebagai bagian dari kebutuhan pasien secara keseluruhan. 
Kebutuhan spiritual merupakan salah satu kebutuhan dasar yang harus dipenuhi seseorang. Jika seseorang sakit dan tidak mampu melakukan aktivitas, tidak ada yang bisa menyembuhkannya kecuali Sang Pencipta. Orang yang menghadapi penyakit serius yang dianggap sakit parah akan memiliki pemahaman yang tinggi tentang keyakinan mereka. Aspek mental dapat membantu membangkitkan semangat pasien dalam proses pemulihan (Asmadi, 2008).

Pasien di unit perawatan intensif adalah pasien sakit kritis yang membutuhkan perawatan intensif. Kondisi ini akan mempengaruhi kondisi psikologis, sosial dan spiritual klien. Pasien di unit perawatan intensif biasanya menderita sakit fisik, ketidaktahuan, dan kematian. Pasien yang tidak yakin akan arti kematian lebih mungkin mengalami gangguan spiritual (Cavendish et al., 2013).

Perawatan spiritual merupakan suatu praktik dan prosedur yang dilakukan oleh perawat pada pasien untuk memenuhi kebutuhan spiritual pasien (Cavendish et al., 2013).

Penelitian Tauhid (2016) tentang kinerja perawat dalam memenuhi kebutuhan spiritual pada pasien kecemasan prabedah menunjukkan bahwa 59 perawat $(96,7 \%)$ berkinerja buruk dalam memenuhi kebutuhan spiritual pada tahun 2016, dengan 2 perawat (3, $3 \%$ ) bekerja dengan baik dalam memenuhi kebutuhan spiritual.
Berdasarkan hasil penelitian pendahuluan berupa wawancara dengan perawat di ruang ICU RSUD Tjitrowardojo Purworejo ditemukan bahwa perawat merasa kurang yakin dalam memberikan perawatan spiritual. Perawat percaya bahwa mereka belum menguasai kemampuan dan keterampilan agama, sehingga mereka tidak dapat memberikan perawatan spiritual terbaik kepada pasien.

Berdasarkan hal diatas maka peneliti tertarik ingin melakukan penelitian yang bertujuan untuk mengetahui Persepsi Perawat tentang Kebutuhan Kebutuhan Spiritual di Ruang ICU.

\section{Metode}

Metode penelitian yang digunakan dalam penelitian ini adalah dengan menggunakan eksplorasi deskriptif kualitatif dengan partisipan adalah perawat ICU RSUD Dr. Tjitrowardojo Purworejo.

\section{Hasil}

1. Karakteristik Partisipan

Partisipan dalam penelitian ini sebanyak 6 perawat. Mereka dipilih sebagai partisipan sesuai kriteria inklusi dalam penelitian ini adalah perawat ICU di ruang ICU RSUD Dr. Tjitrowardojo Purworejo dengan status PNS dan Non PNS, semua partisipan dilakukan wawancara oleh peneliti dengan waktu rata-rata sekitar 15- 
17 menit. Adapun karakteristik partispan ditampilkan dalam Tabel 1.

Tabel 1. Karakteristik Partisipan Perawat ICU RSUD Tjitrowardojo Purworejo

\begin{tabular}{ccccc}
\hline P & Umur & $\begin{array}{c}\text { Lama } \\
\text { Kerja }\end{array}$ & Pendidikan & Pelatihan \\
\hline P1 & 27 & 3 & S1 & Pelatihan ICU \\
P2 & 26 & 2 & D III & Pelatihan ICU \\
P3 & 25 & 2 & D III & Pelatihan ICU \\
P4 & 24 & 3 & D III & Pelatihan ICU \\
P5 & 30 & 2 & D III & Pelatihan ICU \\
P6 & 25 & 2 & D III & Pelatihan ICU \\
\hline
\end{tabular}

2. Proses Penentuan Tema

Analisa data kualitatif menggunakan NVivo Plus 12 untuk mengolah data hasil wawancara. Analisa data menghasilkan tema kebutuhan spiritual pasien yang terdiri dari 2 kategori yaitu pemberian dan pemenuhan.

Tema kebutuhan spiritual pasien terdiri dari 2 kategori yaitu pemberian dan pemenuhan. Kebutuhan spiritual pasien (pemberian dan pemenuhan) melibatkan pasien non muslim dan muslim. Pada pasien non muslim melalui tim rohani dan mengingatkan, pasien muslim melalui tim rohani, melalaui shalat, mengingat Allah, mendoakan, motivasi, adanya fasilitas ibadah dan pendampingan.

“...istilahnya disini memberikan, memfasilitasi pelayanan rohaniawan. Rohaniawan sesuai dengan agama yang dianut si pasien itu sendiri.... kalau intervensi individual paling mendoakan, mendoakan, ya mendoakan, mendoakan, terus mensupport secara, secara rohani, secara motivasi lah, motivasi agar, bahwa setiap apa yang diberikan, apa, penyakit yang diberikan insya Allah ada obatnya......"(P5) terus nanti itupun adannya jam kerja...." (P8)

“....tim rohaniawan itu nanti kalau bahasa kita menyampaikan ke pasien ya pak kyai, rumah sakit seperti itu kalau memang membutuhkan untuk pendampingan pasien gitu bisa, tapi nanti daftar dulu ke perawat..." (P4)

\section{Pembahasan}

Penelitian ini menghasilkan tema kebutuhan spiritual pasien yaitu pemberian dan pemenuhan dimana melibatkan pasien non muslim dan muslim. Pada pasien non muslim dan muslim kebutuhan spiritual dilakukan melalui tim rohani, melalui shalat, mengingat Allah, mendoakan, motivasi, adanya fasilitas ibadah dan pendampingan dari tim rohani.

Kristen et al., (2014) menyatakan bahwa perawat mendorong pasien dengan mendengarkan keluhannya, membaca doa bersama, dan merawat pasien yang sakit kritis melalui spiritual care.

Perawatan spiritual bisa dilakukan dengan mengajari berdoa, mendengarkan keluahan dan cerita, selalu berdoa sebelum aktivitas, mengingatkan shalat lima waktu, memotivasi pasien untuk sembuh dan saat merasakan sakit, menghubungi layanan bian rohani atau pemuka agama (Ristianingsih dkk, 2014). Intervensi lain dapat dilakukan dengan mendorong pasien untuk berpartisipasi atau berinteraksi dengan 
orang yang dicintai, keluarga besar, memberikan waktu dan privasi untuk beribadah, mendengarkan lagu-lagu spiritual dan memfasilitasi alat ibadah (Bulechek, 2013).

Berdasarkan hasil penelitian diatas, kebutuhan spiritual pasien (muslim dan non muslim) dilakukan melalui shalat, mengingat Allah, mendoakan, motivasi, adanya penyediaan fasilitas ibadah dan pendampingan dari tim rohani. Hasil penelitian ini sejalan dengan penelitian yang dilakukan oleh Kristen et al., (2014) yang menyatakan bahwa perawat mendorong pasien dengan mendengarkan keluhannya, membaca doa bersama, dan merawat pasien yang sakit kritis melalui spiritual care.

\section{Kesimpulan}

Dari paparan di atas maka penulis menarik kesimpulan bahwa kebutuhan spiritual merupakan kebutuhan dasar yang dibutuhkan oleh pasien di ruang ICU.

\section{Ucapan Terimakasih}

Penulis mengucapkan terima kasih kepada Direktur Akper Pemkab Purworejo dan Ketua Lembaga Penelitian dan Pengabdian Masyarakat yang telah memberikan dukungan dalam penyelesaian publikasi ini.

\section{Daftar Pustaka}

Asmadi. (2008). Konsep Dasar Keperawatan (Cetakan 1). Jakarta:EGC. https://opac.perpusnas.go.id/DetailOpac.as

$$
\mathrm{px} ? \mathrm{id}=21410
$$

Bulechek, et al. (2013). Nursing Interventions Classification (NIC) (6th edition). Jakarta:Elsevier Mosby.

Cavendish R, et al. (2013). Spiritual Care Activities of Nurses Using Nursing Interventions Classification (NIC) Labels. International Journal of Nursing Terminologies and Classification, 14, 113122.

https://doi.org/https://doi.org/10.1111/j.17 44-618x.2003.00113.x

Hamid, A. Y. S. (2010). Buku Ajar Aspek Spiritual dalam Keperawatan. Jakarta:Widya Medika.

Hawari, D. (2012). Kebutuhan Spiritual. Jakarta:UI Press.

Kristen AT et al. (2014). The Power of Consoling Presence-Hopice Nurse' Lived Experience with Spiritual and Existential Care for The Dying. BMC Nursing. https://doi.org/https://doi.org/10.1186/147 2-6955-13-25

Ristianingsih, dkk. (2014). Gambaran Motivasi dan Tindakan Keperawatan dalam Pemenuhan Kebutuhan Spiritual Pasien di Ruang ICU PKU Muhammadiyah Gombong. Jurnal Ilmiah Kesehatan Keperawatan, 10(2), 91-99. http://ejournal.stikesmuhgombong.ac.id/JI KK/article/view/131/123

Tauhid, A. I. \& R. A. (2016). Hubungan Kinerja Perawat pada Pemenuhan Aspek Spiritual dengan Tingkat Kecemasan Pasien Pre Operasi di RSUD Ungaran. https://123dok.com/document/yerl1weqhubungan-kinerja-perawat-pemenuhanspiritual-tingkat-kecemasan-operasi.html 